\title{
Inoculation and co-inoculation of growth promoting rhizobacteria in irrigated rice plants
}

Franciane Lemes dos Santos ${ }^{1} \oplus$, Franquiéle Bonilha da Silva ${ }^{1} \oplus$, Enilson Luiz Saccol de Sá1®, André Luis Vian ${ }^{1}\left[\right.$, Aleksander Westphal Muniz²®, Rafael Nunes dos Santos ${ }^{3}(\mathbb{0}$

\footnotetext{
1 Universidade Federal do Rio Grande do Sul, Faculdade de Agronomia, Porto Alegre, RS, Brasil. E-mail: franciane_lemes@hotmail.com; franquiele_bonilha@yahoo.com.br; enilson.sa@gmail.com; andre.vian@ufrgs.br

${ }^{2}$ Embrapa Amazônia Ocidental, Manaus, AM, Brasil. E-mail: aleksander.muniz@embrapa.br

${ }^{3}$ Instituto Rio Grandense do Arroz, Cachoeirinha, RS, Brasil. E-mail: rafael-santos@irga.rs.gov.br
}

ABSTRACT: Aiming at obtaining high productivity and reduction of production costs, new techniques have been studied in rice crops, such as the use of plant growth promoting rhizobacteria (PGPR). The objective of this study was to evaluate the efficiency of inoculation and co-inoculation of rhizobia and Azospirillum brasilense in promoting the growth of irrigated rice plants cultivated in the field. Two experiments were conducted in the field, in the 2014/15 and 2015/16 crops, at the Rio Grande do Sul Rice Experiment Station. The experiment was composed of seven treatments, with two control treatments, without inoculation (81 $\mathrm{kg} \mathrm{ha}^{-1} \mathrm{~N}$ and $135 \mathrm{~kg} \mathrm{ha}^{-1} \mathrm{~N}$, equivalent to $60 \%$ and $100 \%$, respectively, of the recommended nitrogen dose). The other five treatments received only $60 \%$ of the $\mathrm{N}$ dose and were inoculated with the UFRGS Vp16 (Burkholderia sp.) and UFRGS LC348 (Mesorhizobium sp.) Rhizobia, and with the commercial product containing the A. brasilense AbV5 and AbV6 strains. Inoculation and co-inoculation with PGPR may represent a viable alternative to reduce the amount of nitrogen fertilizers in rice crops.

Key words: Azospirillum sp.; Oryza sativa; rhizobium; yield

\section{Inoculação e coinoculação de rizobactérias promotoras de crescimento em plantas de arroz irrigado}

RESUMO: Visando a obtenção de altas produtividades e redução dos custos de produção, novas técnicas vêm sendo estudadas nas lavouras de arroz, como a utilização de rizobactérias promotoras de crescimento de plantas (RPCPs). O objetivo do trabalho foi avaliar a eficiência da inoculação e coinoculação de rizóbios e Azospirillum brasilense na promoção de crescimento de plantas de arroz irrigado cultivadas a campo. Foram conduzidos dois experimentos a campo, nas safras 2014/15 e 2015/16, na Estação Experimental do Instituto Rio Grandense do Arroz. O experimento foi composto por sete tratamentos, sendo dois tratamentos controle, sem inoculação (81 kg ha-1 de N e $135 \mathrm{~kg} \mathrm{ha}^{-1} \mathrm{~N}$, equivalente a $60 \%$ e $100 \%$, respectivamente, da dose de nitrogênio recomendada). Os outros cinco tratamentos receberam apenas $60 \%$ da dose de $\mathrm{N}$ e foram inoculados com os rizóbios UFRGS Vp16 (Burkholderia sp.) e UFRGS Lc348 (Mesorhizobium sp.), e com o produto comercial contendo as estirpes de A. brasilense AbV5 e AbV6. A inoculação e coinoculação com RPCPs podem representar uma alternativa viável para reduzir a quantidade de adubos nitrogenados nas lavouras de arroz.

Palavras-chave: Azospirillum sp.; Oryza sativa; rizóbio; produtividade 


\section{Introduction}

Brazil excels as one of the most important countries in terms of rice production and consumption in the world, producing over 10 million tons in the 2018/19 crop, and the state of Rio Grande do Sul is the largest national producer with almost $70 \%$ of production (Conab, 2019).

Although rice agribusiness enjoys favorable conditions for its development, there are production factors that may restrict this expansion, including the availability of nitrogen. In order to obtain high grain yields, a common practice of the producing countries is to use high doses of nitrogen fertilizers in rice farms, usually exceeding the recommended dosage of $150 \mathrm{~kg} \mathrm{~N} /$ ha (Sosbai, 2018). Nitrogen is a high cost fertilizer and its excessive use can cause damage to the environment (Pinto et al., 2017).

A promising alternative for reducing fertilizer use and increasing rice crop productivity is the use of beneficial plant-associated microorganisms, plant growth promoting rhizobacteria (PGPR). PGPRs are bacteria that live in the rhizosphere and directly or indirectly promote plant growth (Sarkar \& Reinhold-Hurek, 2014), either by their ability to produce plant hormones (auxins, gibberellins and cytokines), solubilize nutrients (Kavamura et al., 2012), or reduce the damage caused by phytopathogens (Ferraz et al., 2010).

Several studies have been conducted demonstrating the colonization of PGPRs in rice plant roots and their effect on promoting the growth of this said poaceae (Chaves et al., 2016; Garcia et al., 2016; Osorio Filho et al., 2016). However, responses of cultivars are different to the inoculation, demonstrating that the ability in promoting growth from the PGPRs can be specific for each cultivar, i.e., the technique success is directly related to the interaction between plant genotype and bacterial strains, as well as the factors related to the environment (type of soil and climate).

Although the results of employing PGPRs are promising, there is still a lack of studies showing the interaction of rhizobia, symbionts in vegetables, with different rice genotypes used in the state of Rio Grande do Sul. Thus, the objective of this study was to evaluate the efficiency of rhizobia and Azospirillum brasilense inoculation and co-inoculation in the growth promotion of irrigated rice plants cultivated in field.

\section{Materials and Methods}

The experiments were performed in the field at the Experimental Station of the Rio Grandense do Arroz Institute (IRGA), in the Cachoeirinha municipality, part of the rice region of the Central Depression from Rio Grande do Sul State, in a typical dystrophic Haplic Gleysol of loamy texture, in the 2014/15 and 2015/16 crops. Prior to the installation of the experiment (2014/15 crops), the area was in fallow state for two years.

The experiment consisted of seven treatments (Table $1)$, with two control treatments without inoculation: one that received $81 \mathrm{~kg} \mathrm{ha}^{-1} \mathrm{~N}$ and another with $135 \mathrm{~kg} \mathrm{ha}^{-1} \mathrm{~N}$,
Table 1. Identification and description of the treatments.

\begin{tabular}{lcc}
\multicolumn{1}{c}{ Treatment } & Fertilizer & Strains \\
\hline Control $60 \% \mathrm{~N}$ & $81 \mathrm{~kg} \mathrm{ha}^{-1} \mathrm{~N}$ & - \\
Control $100 \% \mathrm{~N}$ & $135 \mathrm{~kg} \mathrm{ha}^{-1} \mathrm{~N}$ & - \\
$60 \% \mathrm{~N}+\mathrm{Vp} 16$ & $81 \mathrm{~kg} \mathrm{ha}^{-1} \mathrm{~N}$ & UFRGS Vp16 \\
$60 \% \mathrm{~N}+\mathrm{Lc} 348$ & $81 \mathrm{~kg} \mathrm{ha}^{-1} \mathrm{~N}$ & UFRGS Lc348 \\
$60 \% \mathrm{~N}+$ Azosp. & $81 \mathrm{~kg} \mathrm{ha}^{-1} \mathrm{~N}$ & Azosp. \\
$60 \% \mathrm{~N}+$ Az. $+\mathrm{Vp} 16$ & $81 \mathrm{~kg} \mathrm{ha}^{-1} \mathrm{~N}$ & Azosp.+ Vp16 \\
$60 \% \mathrm{~N}+$ Azp.+Lc348 & $81 \mathrm{~kg} \mathrm{ha}^{-1} \mathrm{~N}$ & Azosp.+Lc348 \\
\hline
\end{tabular}

equivalent to $60 \%$ and $100 \%$, respectively, same nitrogen dosage recommended and described by CQFS RS/SC (2004). The other five treatments received only $60 \%$ of the $N$ dose (81 $\mathrm{kg} \mathrm{ha}^{-1}$ ) and were inoculated with the rhizobia UFRGS Vp16 (Burkholderia sp.), isolated from white clover (Trifolium repens) by Alves (2005), and UFRGS Lc348 (Mesorhizobium sp.), isolated from birdsfoot trefoil (Lotus corniculatus) by Frizzo (2007), and with the commercial product containing Azospirillum brasilense strains AbV5 and AbV6. Inoculation was both isolated and combined (co-inoculation). The experimental design was the randomized blocks, with three replicates.

IRGA 424 was the cultivar used, which has high yield potential and good response to fertilization. In both crops, the used sowing density was $120 \mathrm{~kg} \mathrm{ha}^{-1}$, with row spacing of $0.17 \mathrm{~m}$. Seeds were treated with fungicide and insecticide, and fertilization at planting was of $400 \mathrm{~kg} \mathrm{ha}^{-1}$ NPK in the 0417-27 formula, for expectation of "Very High" response to fertilization (Sosbai, 2014).

Topdressing nitrogen fertilization with urea $(46 \% \mathrm{~N})$ was performed by applying $2 / 3$ of the dosage at the V3-V4 stage and the remainder between V7 and V8 stages, before panicle differentiation. Irrigation started between V3 and V4 stages, by keeping a water depth of about $7.5 \mathrm{~cm}$ throughout the whole crop cycle. Between the R7/R8 stages, when most grains were in the pasty to farinaceous state, the irrigation was suppressed. Control of diseases, pests and weeds was carried out according to the technical recommendations for irrigated rice in southern Brazil (Sosbai, 2014).

For producing the bacterial inoculum, each rhizobium was inoculated in a $\mathrm{pH}$ 6.8 Yeast Mannitol (YM) culture medium in a $1000 \mathrm{ml}$ capacity erlenmeyer flask kept in an incubator with $120 \mathrm{rpm}$ orbital shaking for six days at $28^{\circ} \mathrm{C}$. Bacterial inoculation in the plants of the inoculated treatments was performed by sprinkling when the plants were in the V3-V4 stages, before the irrigation start. The $200 \mathrm{ml} \mathrm{ha}^{-1}$ dose of bacterial inoculum from each rhizobium (containing about $10^{8} \mathrm{CFU} \mathrm{ml} \mathrm{m}^{-1}$ ) and $100 \mathrm{ml} \mathrm{ha}^{-1}$ of the commercial product (at the $2.0 \times 10^{8}$ concentration guaranteed by the manufacturer, containing the $A$. brasilense AbV5 and Abv6 strains), diluted in water for spraying on plants.

The analyzed variables were grain yield and yield components (number of panicles per square meter, number of grains per panicle and grain weight). Results of yield components, when necessary, were transformed using the function $v(x+1)$. After this procedure, the results were 
subjected to the analysis of variance by the Scott-Knott test (p. 0.10), using the statistical program SISVAR (Ferreira, 2000).

\section{Results and Discussion}

Results of yield components (panicle number $/ \mathrm{m}^{2}$, grain number/panicle number and 1000 grains weight) are displayed in Table 2. Inoculation and co-inoculation of growth promoting bacteria in rice plants promoted significant increase only in the number of panicles per square meter variable, at the $2014 / 2015$ crop.

In the first evaluated crop (2014/2015), plants inoculated alone with $A$. brasilense and co-inoculated with UFRGS Lc348 and $A$. brasilense presented higher number of panicles $/ \mathrm{m}^{2}$ than the other treatments, with an increase of up to $12.2 \%$ when compared to the control treatment that had the $100 \%$ nitrogen dose.

The number of panicles per unit area is defined in the plant vegetative phase, thus, it can be stated that inoculation or coinoculation with UFRGS Lc348 and A. brasilense favored the crop vegetative phase, increasing the number of panicles with only $60 \%$ of the recommended nitrogen dose (Table 2 ), confirming the hypothesis that inoculation of PGPRs stimulate the development of rice plants throughout the crop cycle, directly interfering with yield components (Osorio Filho et al., 2016).

Absence of significant results for the other yield components is understandable, as the literature indicates that the PGPRs action on rice plants is variable (Buzo et al., 2019), since several factors may contribute to different rice responses to the PGPRs inoculation, being among them the used bacterial strain, edaphoclimatic conditions and the specificity with the plant genotype (Hungria, 2011). This very inconsistency of research results is one of the main obstacles to the PGPRs use in crops.

However, this study results reinforce the existence of beneficial interactions from PGPRs with rice plants, probably due to the increased levels of phytohormones in the tissues, especially the indole-3-acetic acid (IAA) (Osorio Filho et al., 2016). Phytohormones produced by PGPRs act at all plant development stages, and each bacterial isolate can differently stimulate production levels of specific plant hormones, which are significantly reflected in the rice plants growth physiology (Chi et al., 2005).
Regarding grain yield, the analysis of variance results showed that inoculation and co-inoculation with PGPRs associated with $60 \%$ of the recommended nitrogen dose $(81 \mathrm{~kg}$ $\mathrm{ha}^{-1} \mathrm{~N}$ ) provides the same rice grain yield as the recommended crop dose (135 kg ha-1 N). The inoculations with UFRGS Lc348 in the 2014/2015 crop, and inoculation and co-inoculation of UFRGS Vp16, UFRGS Lc348 and A. brasilense in the 2015/2016 crop all evidenced this (Figure 1 ).

In the $2014 / 2015$ crop, the co-inoculation of the rhizobium UFRGS Lc348 plus A. brasilense produced $10,206.86 \mathrm{~kg}$ of rice per hectare, similar to the control treatment production with $100 \%$ of the recommended $\mathrm{N}$ dose $\left(10,083.85 \mathrm{~kg} \mathrm{ha}^{-1}\right)$. Coinoculation of rhizobia UFRGS Lc348 and $A$. brasilense showed better results than when PGPRs were inoculated singly in plants, proving the synergistic effect of the technique. In other words, the result of the bacterial combination was more effective in increasing grain yield than a single inoculation.

Inoculation and co-inoculation also favored the grain production of the 2015/16 crop. All inoculated or coinoculated treatments produced grains equivalent to the control treatment with the $100 \%$ nitrogen dose (Figure 1). The good performance of PGPRs on rice grain yield shows that standard inoculation or co-inoculation is an alternative to reduce up to $40 \%$ the amount of nitrogen fertilizer in rice production.

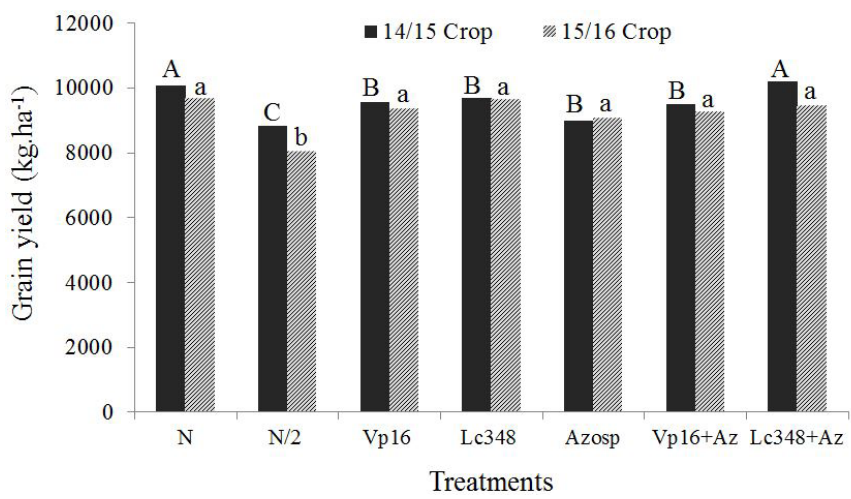

Figure 1. Grain yield of rice plants inoculated and co-inoculated with plant growth promoting rhizobacteria, 2014/15 and 2015/16 crops. Means followed by the same letter do not differ from each other ( $p \geq 0.10$, Scott-Knott). Capital letters for 2014/15 crop, lowercase letters for 2015/16 crop.

Table 2. Yield components (number of panicles $/ \mathrm{m}^{2}$, number of grains/panicle and 1000 grains weight) of irrigated rice plants inoculated and co-inoculated with plant growth promoting rhizobacteria, 2014/15 and 2015/16 crops.

\begin{tabular}{lcccccc}
\hline \multirow{2}{*}{ Treatments } & \multicolumn{2}{c}{ Number of panicles/m² } & \multicolumn{2}{c}{ Number of grains/panicle } & \multicolumn{2}{c}{ 1000 grains weight (g) } \\
\cline { 2 - 6 } & 2014/15 crop & 2015/16 crop & 2014/15 crop & 2015/16 crop & 2014/15 crop & 2015/16 crop \\
\hline Control 60\%N & $642.0 \mathrm{~b}$ & $673.0 \mathrm{a}$ & $56.4 \mathrm{a}$ & $54.2 \mathrm{a}$ & $29.8 \mathrm{a}$ & $27.6 \mathrm{a}$ \\
Control 100\%N & $690.4 \mathrm{~b}$ & $811.7 \mathrm{a}$ & $60.9 \mathrm{a}$ & $67.2 \mathrm{a}$ & $27.9 \mathrm{a}$ & $28.9 \mathrm{a}$ \\
$60 \% \mathrm{~N}+\mathrm{Vp16}$ & $705.6 \mathrm{~b}$ & $780.0 \mathrm{a}$ & $58.7 \mathrm{a}$ & $69.2 \mathrm{a}$ & $28.6 \mathrm{a}$ & $29.4 \mathrm{a}$ \\
$60 \% \mathrm{~N}+$ Lc348 & $669.7 \mathrm{~b}$ & $741.0 \mathrm{a}$ & $57.1 \mathrm{a}$ & $70.2 \mathrm{a}$ & $30.1 \mathrm{a}$ & $31.2 \mathrm{a}$ \\
$60 \% \mathrm{~N}+$ Azosp. & $752.5 \mathrm{a}$ & $740.7 \mathrm{a}$ & $58.0 \mathrm{a}$ & $63.2 \mathrm{a}$ & $29.4 \mathrm{a}$ & $28.4 \mathrm{a}$ \\
$60 \% \mathrm{~N}+$ Az.+Vp16 & $646.2 \mathrm{~b}$ & $800.0 \mathrm{a}$ & $63.5 \mathrm{a}$ & $78.0 \mathrm{a}$ & $29.1 \mathrm{a}$ & $29.6 \mathrm{a}$ \\
$60 \% \mathrm{~N}+$ Azp.+Lc348 & $787.0 \mathrm{a}$ & $753.0 \mathrm{a}$ & $54.0 \mathrm{a}$ & $77.5 \mathrm{a}$ & $28.6 \mathrm{a}$ & $29.8 \mathrm{a}$ \\
CV (\%) & 8.36 & 6.82 & 10.26 & 16.74 & 4.96 & 4.20 \\
\hline
\end{tabular}

Means followed by the same letter does not differentiate from each other ( $p \geq 0.10$, Scott-Knott). 
The 2015/2016 crop in the state of Rio Grande do Sul, the largest national producer, had a $14.7 \%$ drop in average yield, due to the unfavorable climate during the harvest period (Conab, 2017). However, even under unfavorable conditions for cultivation in the state, plants inoculated with PGPRs increased grain yield with only $60 \%$ of the recommended nitrogen dose. Similar results were found by Ferreira et al. (2010), who observed that the inoculated treatments were able to supply a dosage equivalent to $20 \mathrm{~kg}$ of $\mathrm{N} \mathrm{ha}^{-1}$, and Baldani \& Baldani (2005) reported a reduction up to $30 \%$ of the expenses with nitrogen fertilizers applied to irrigated rice.

Considering the average yield of the state of Rio Grande do Sul, 7,914 $\mathrm{kg} \mathrm{ha}^{-1}$ (Irga, 2016), the results displayed in this study represent a grain yield increase of $22.5 \%$ and $18 \%$ in the 2014/15 and 2015/16 crops, respectively. Benefits of inoculation on grain yield of rice cultivars have also been observed by several authors (Chaves et al., 2016; Nascente et al., 2016; Rais et al., 2016).

This study shows that the PGPRs use in rice fields will be an economically viable alternative for rice farmers due to the high price of nitrogen fertilizers, thus, saving $54 \mathrm{~kg} \mathrm{ha}^{-1}$ with these inputs would mean a lower production cost, increased agricultural yield income and lower environmental impact potential. Therefore, a better understanding of the interactions between rice cultivars and PGPRs is of fundamental importance so that, in the future, the inoculation and coinoculation techniques can be used in the crops, striving for the production system sustainability.

\section{Conclusions}

Inoculation and co-inoculation of rhizobia UFRGS-VP16 and UFRGS Lc348, and of Azospirillum brasilense increase the number of panicles per square meter compared to the treatment without inoculation and with $60 \%$ of the nitrogen dose.

Co-inoculation of the rhizobium UFRGS Lc348+Azospirillum, associated with $60 \%$ of the nitrogen dose, maintains the grain yield of the IRGA 424 rice cultivar when compared to the recommended $100 \%$ nitrogen dose.

In a previously inoculated area (2015/2016 crop), inoculation with PGPRs had positive effect on grain yield in rice plants with $60 \%$ of the recommended nitrogen dose.

\section{Literature Cited}

Alves, J.B. Seleção de rizóbios para trevo branco. Porto Alegre: Universidade Federal do Rio Grande do Sul, 2005. 78p. Dissertação Mestrado. https://www.lume.ufrgs.br/handle/10183/8864. 22 Jun. 2018.

Baldani, V.L.D.; Baldani, J.I. History on the biological nitrogen fixation research in graminaceous plants: special emphasis on the Brazilian experience. Anais da Academia Brasileira de Ciências, v.77, n.3, p.549-579, 2005. https://doi.org/10.1590/S000137652005000300014 .
Buzo, F.S.; Garé, L.M.; Arf, O.; Portugal, J.R.; Meirelles, F.C.; Garcia, N.F.S. Interaction between thidiazuron and Azospirillum brasilense on yield characteristics and productivity of rice. Revista Brasileira de Engenharia Agrícola e Ambiental, v.23, n. 4, p. 244-249, 2019. https://doi.org/10.1590/1807-1929/agriambi. v23n4p244-249.

Chaves, J.S.; Miranda, A.F.M.; Santana, A.S.; Rodríguez, C.A.; Silva, E.S. Eficiência da inoculação na cultura do arroz (Oryza sativa L.) no sul do estado de Roraima. Revista Eletrônica Ambiente, Gestão e Desenvolvimento, v.9, n.2, p.75-84, 2016. https://remgads.uerr. edu.br/index.php/home/article/view/35. 18 Jun. 2018.

Chi, F.; Shen, S.H.; Cheng, H.P.; Jing, Y.X.; Yanni, Y.G.; Dazzo, F.B. Ascending migration of endophytic rhizobia, from roots to leaves, inside rice plants and assessment of benefits to rice growth physiology. Applied and Environmental Microbiology, v.71, n.11, p.7271-7278, 2005. https://doi.org/10.1128/AEM.71.11.72717278.2005.

Companhia Nacional de Abastecimento - Conab. Acompanhamento da safra brasileira: grãos, safra 2017/2018, primeiro levantamento. v. 5 - Safra 2017/18, n.1, p.1-114, 2017. https:// www.conab.gov.br/info-agro/safras/graos/boletim-da-safra-degraos/item/download/12565_70ce8f808de9b37964d1111338f9 7d8a. 13 Mai. 2018.

Companhia Nacional de Abastecimento - Conab. Acompanhamento da safra brasileira: grãos, safra 2018/2019, quarto levantamento. v. 6 - Safra 2018/19, n.4, p.1-126, 2019. Fevereiro 2019. v.6. Brasília: Conab, 2019. 125p. https://www.conab.gov.br/infoagro/safras/graos/boletim-da-safra-de-graos/item/download/2 3999_57b97f236e2bf03f1f87c796a16fab99. 13 Mai. 2018.

Comissão de Química e Fertilidade do Solo dos Estados do Rio Grande do Sul e Santa Catarina - CQFS-RS/SC. Manual de adubação e calagem para os estados do Rio Grande do Sul e Santa Catarina. Porto Alegre: SBCSNRS; EMBRAPA-CNPT, 2004. 400p.

Ferraz, S.; Freitas, L.G.; Lopes, E.A.; Dias-Arieira, C.R. Manejo sustentável de fitonematoides. Viçosa: Editora UFV, 2010. 304p.

Ferreira, D.F. Manual do sistema Sisvar para análises estatísticas. Lavras: Universidade Federal de Lavras, 2000.66p.

Ferreira, J. S.; Baldani, J. I.; Baldani, V.L.D. Seleção de inoculantes à base de turfa contendo bactérias diazotróficas em duas variedades de arroz. Acta Scientiarum. Agronomy, v.32, n.1, p.179-185, 2010. https://doi.org/10.4025/actasciagron.v32i1.73210.4025/ actasciagron.v32i1.732.

Frizzo, M.L.S. Seleção e caracterização de rizóbios nativos, de solos do Rio Grande do Sul, para Lotus corniculatus L. e Lotus uliginosus Schkuhr. Porto Alegre: Universidade Federal do Rio Grande do Sul, 2007. 68p. Dissertação Mestrado. https://www.ufrgs.br/ agronomia/materiais/marfrizzo.pdf. 22 Jun. 2018.

Garcia, N. F. S.; Arf, O.; Portugal, J. R.; Peres, A. R.; Rodrigues, M.; Penteado, M. de S. Doses and application methods of Azospirillum brasilense in irrigated upland rice. Revista Brasileira de Engenharia Agrícola e Ambiental, v.20, n.11, p.990-995, 2016. https://doi.org/10.1590/1807-1929/agriambi.v20n11p990-995. Hungria, M. Inoculação com Azospirillum brasiliense: inovação em rendimento a baixo custo. Londrina: Embrapa Soja, 2011. $36 \mathrm{p}$. 
Instituto Rio-Grandense do Arroz - Irga. Média de produtividade do arroz no RS foi a melhor dos últimos tempos. http://www. rs.gov.br/conteudo/260822/media-de-produtividade-do-arrozno-rs-foi-a-melhor-dos-ultimos-tempos/termosbusca=*. Dez. 2017.

Kavamura, V.N.; Santos, S.N.; Silva, J.L.; Parma, M.M.; Avila, L.A.; Visconti, A.; Zucchi, T.D.; Taketani, R.G.; Andreote, F.D.; Melo, I.S. Screening of brazilian cacti rhizobacteria for plant growth promotion under drought. Microbiological Research, v. 168, n.4, p. 183-191, 2012. https://doi.org/10.1016/j. micres.2012.12.002.

Nascente, A.S.; Filippi, M.C.C.; Lanna, A.C. Biomass, gas exchange, and nutrient contents in upland rice plants affected by application forms of microorganism growth promoters. Environmental Science and Pollution Research, v. 24, n. 3, p. 2956-2965, 2017. https://doi.org/10.1007/s11356-016-8013-2.

Osorio Filho, B.D.; Binz, A.; Lima, R.F.; Giongo, A.; Sá, E.L.S. Promoção de crescimento de arroz por rizóbios em diferentes níveis de adubação nitrogenada. Ciência Rural, v.46, n.3, p.478-485. 2016. https://doi.org/10.1590/0103-8478cr20141066.
Pinto, V.M.; Bruno, I.P.; Lier, Q.J.V.; Dourado Neto, D.; Reichardt, K. Uso excessivo de nitrogênio gera perda monetária para cafeicultores do cerrado baiano. Coffee Science, v.12, n.2, p.176-186. 2017. http:// www.sbicafe.ufv.br:80/handle/123456789/8641. 18 Jun. 2018.

Rais, A.; Shakeel M.; Hafeez, F.Y.; Hassan, M.N. Plant growth promoting rhizobacteria suppress blast disease caused by Pyricularia oryzae and increase grain yield of rice. BioControl, v.61, n.6, p.769-780, 2016. https://doi.org/10.1007/s10526-016-9763-y.

Sarkar, A.; Reinhold-Hurek, B. Transcriptional profiling of nitrogen fixation and the role of NifA in the diazotrophic endophyte Azoarcus sp. strain BH72. Plos One, v.9, n.2, p.1-12, 2014. https:// doi.org/10.1371/journal.pone.0086527.

Sociedade Sul-Brasileira de Arroz Irrigado - Sosbai. Arroz Irrigado: recomendações técnicas da pesquisa para o Sul do Brasil. Itajaí: Reunião Técnica da Cultura do Arroz Irrigado, 2014. 179p.

Sociedade Sul-Brasileira de Arroz Irrigado - Sosbai. Arroz Irrigado: recomendações técnicas da pesquisa para o Sul do Brasil. Cachoeirinha: Sosbai, 2018. 205p.

Vincent, J.M. A manual for the practical study of root nodule bacteria. London: International Biological Programme, 1970. 164 p. 